\title{
Minds in Chains: A Sociocybernetic Analysis of the Abrahamic Faiths ${ }^{1}$
}

\author{
Bernard Scott \\ Centre for Sociocybernetics Research, Bonn
}

\begin{abstract}
I address the troubling matter of 'pathological belief systems', which I have previously defined as those that 'restrict the right of actors to interact'. In particular, I consider the tangled 'Gordian' knot of beliefs that constitute the Abrahamic faiths: Judaism, Christianity and Islam. It is my belief that an analysis based on well-defined cybernetic principles can help cut through this knot and lay bare just what is pathological. The attraction of such an analysis is that it does not require one to pass judgements and 'take sides' with respect to the major controversies that divide the faiths. More generally, a properly formulated sociocybernetic analysis does not require one to pose any fundamental opposition between 'science' and 'religion'. What the analysis does is help identify what are the key differences between 'science' and 'religion' as routes to knowledge and understanding, whilst noting that there are 'undecidable questions' about which an individual should be permitted to formulate her own beliefs without opposition or condemnation from others.
\end{abstract}

url:

A central concern of this paper and some earlier papers I have presented at conferences on sociocybernetics ${ }^{2}$ is with how humanity can cope with the many problems that require a global, coordinated response (Scott, 2009, 2012). The problems include, but are not restricted to: climate change, pollution and other damage to the ecosystem and biosphere, population increase, social justice and sustainable development and how to mitigate associated problems of poverty and lack of opportunities for personal empowerment through education. Using concepts from sociocybernetics ${ }^{3}$, I have argued that the problems are inter-related and need to be tackled holistically (Scott, 2002) and that this requires viewing the state of the world as an inter-related 'system of systems', with complementary first and second order aspects. By first order aspects, I mean those that can be observed and measured using the stance of an external observer. By second order aspects, I mean those that require the observer to be a participant observer, if only in the sense that she is according to the 'objects' of her study the status that they, too, are systems that can act as observers and with whom, in an appropriate context, he can converse. This distinction follows that made by von Foerster (1992, 2003) between first order cybernetics, which he defines as the study of observed systems, and second order cybernetics, which he defines as the study of observing systems. I have also discussed the requirement for an 'education for cybernetic enlightenment', one that would facilitate the needed concerted action on a global scale, and have set out, in outline, the core elements of the necessary curriculum (Scott, 2014).

In Scott (2012), I cite Ross Ashby's (1956) Law of Requisite Variety (“Only variety can destroy variety") to argue that we need to generate a sufficient variety of human responses to manage the many challenges facing us. It is thus essential that humans are able to converse in order to agree ways in

Corresponding author: Bernard Scott; e-mail: berncesı@gmail.com 
which to cooperate. In this paper, I wish to address the troubling matter of 'pathological belief systems', which I have defined previously, following Pask (1991), as those that "restrict the right of actors to interact" (Scott, 2009). As an example, I consider the tangled 'Gordian' knot of beliefs that constitute the Abrahamic faiths: Judaism, Christianity and Islam. Various forms of these beliefs are subscribed to by more than $50 \%$ of the world's population, All three faiths deny aspects of each other's beliefs. This not only hinders conversation and cooperation, it has also led to discrimination and outright conflict and continues to do so. It is my belief that an analysis of these faiths, based on welldefined cybernetic principles, can help cut through this knot and lay bare just what is pathological. The attraction of such an analysis is that, whilst it requires at least a broad brush stroke understanding of the central tenets of the three faiths, their similarities and differences and their intertwined histories, it does not require one to pass judgements and 'take sides' with respect to the major controversies that divide the faiths exciept with respect to the extent to which they do or do not incorporate the possibilities for an education for cybernetic enlightenment.

The paper is structured as follows. The paper uses concepts from cybernetics to set out an understanding of what is a belief system and what is intended by saying that a particular belief system is pathological. A distinction is made between beliefs that can be considered to be 'scientific' and those that may not. There then follows a summary of the main tenets of the three Abrahamic faiths, with reference to their historical development and the conflicts that have been engendered within them and between them. The beliefs of the three faiths are then appraised from the perspective of cybernetics. Finally, there are some thoughts about the possibility that better understandings of the human condition could lead to improvements in the human condition.

\section{Belief systems}

The key questions raised in this section are what are belief systems, how are they formed, how are they changed.

\section{What are belief systems}

By a "belief" I refer to a proposition with a supporting narrative (stories, models, laws, rules) that someone (a believer) may hold to be true. Beliefs carry with them (tacitly or explicitly) metaphysical assumptions about how we know and what may be known (epistemology), how the world came into being and what it consists of (ontology) how one should behave (ethics). Beliefs have emotional value. Beliefs may contain different kinds of knowledge: knowing that, how, and why. Well-rehearsed beliefs become proceduralised and exist as tacit knowledge, guiding an individual's behaviour without conscious awareness. Beliefs function as part of the on-going dynamic of conceptualisation, within a shifting field of awareness and meta-awareness.

The general form of a belief system is shown in figure $1^{4}$. Note there are two cycles, both of which should be considered as dynamic and ongoing in the daily praxis of living. The cycle labelled 'why' refers to the processes of conceptualisation, the seeking of explanations that guide and justify behaviour and that are "coherent" or "make sense together" in some way. The cycle labelled 'how' refers to how beliefs affect behaviour. Conceptualisation is a process that all humans engage in, if only in a rudimentary form. More sophisticated conceptualisation explicitly looks for logical coherence within and between explanations. It is important to appreciate that the acceptance of dogmatic 'truths' limits what can be thought about and what can be questioned. A lack of exposure to critical thinking limits the 'tools for thought' that can be used to question beliefs. In the 'how' cycle, only some behaviours may be permitted. Rather than look for evidence for beliefs, one may be obliged to follow set rules and procedures unquestioningly. 


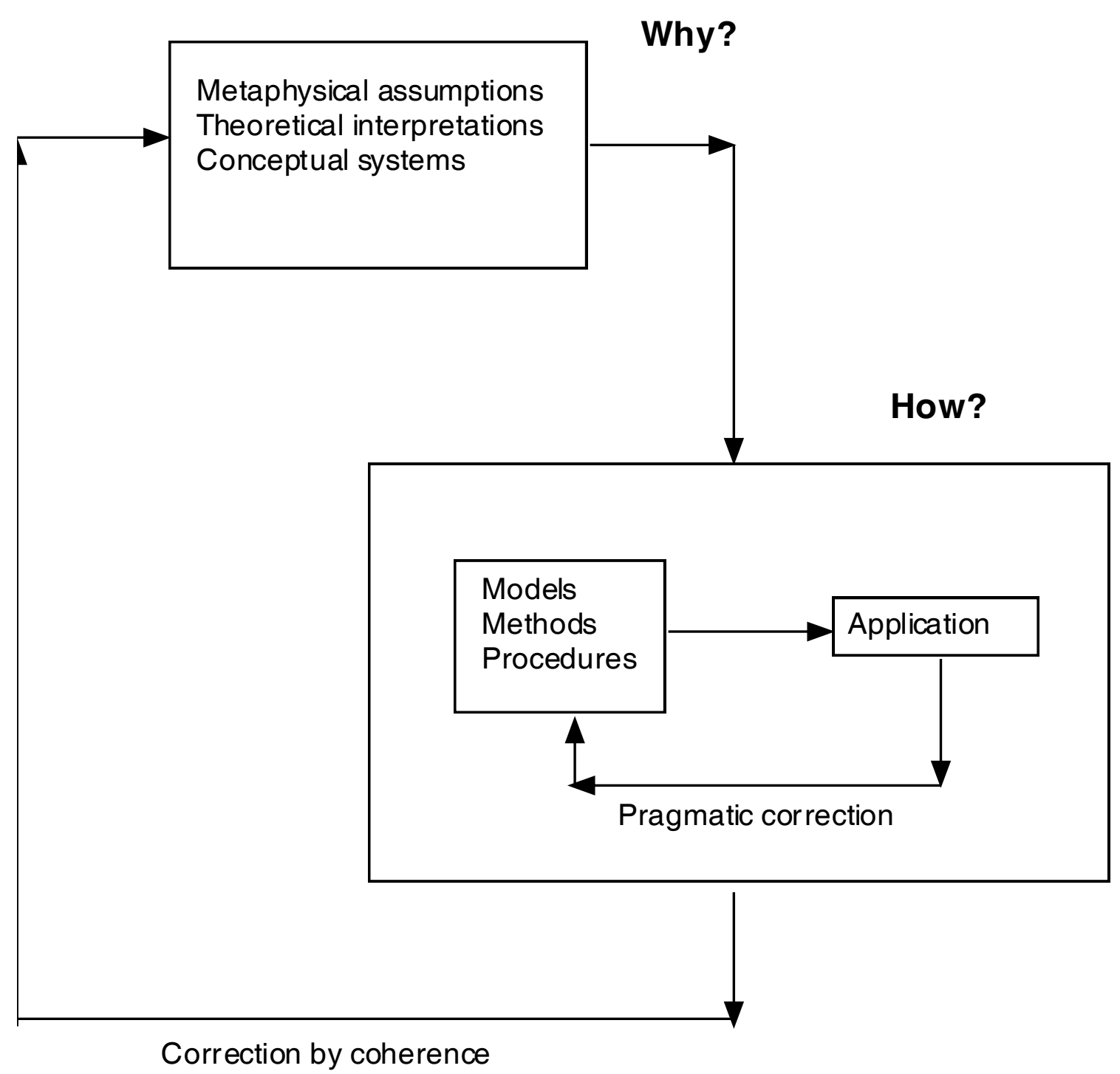

Figure 1. A "system of beliefs" (after Rescher)

It is helpful to contrast the forms of correction required and accepted by scientists with those required and accepted by holders of non-scientific belief systems. A key difference is that science is convergent. Over time, through critical analysis of theories and the testing of hypotheses, a body of accepted knowledge is built up as 'justified true beliefs" ${ }^{5}$. In contrast, "religious' ${ }^{6}$ and other nonscientific belief systems are divergent. ${ }^{7}$ I have coined the aphorism "isms lead to schisms" (L. 'scisma', a split) to capture this idea. As we shall see below, the Abrahamic faiths have, through schisms, generated a bewildering variety of sects and subsects. This is generally true of all faith-based belief systems.

In the case of non-scientific beliefs, it is useful to distinguish between 'authoritarian' and 'philosophic' belief systems. As the name suggests, the former refers to dogmatic belief systems, as prescribed by authority figures or authoritative texts. These systems are designed to be rigid and closed to outside influences. However, as evidenced by the Abrahamic faiths, none are immune to schism. The latter refers to the broad class of belief system that, in their many different ways, use reason to 'think about 
thinking' and to address questions concerning epistemology, ontology and ethics. Such belief systems tend to be open and flexible. Indeed, disputation may be an ongoing activity ${ }^{8}$. The problem with these 'isms' is that their conclusions depend on the a priori assumptions made, which are not always made explicit. Examples of such 'isms' include 'constructivism', 'realism', 'socialism', 'capitalism', 'utilitarianism', 'deism', 'existentialism'. None of the examples has a universally agreed formulation.

\section{How Are Beliefs Formed?}

There are several ways in which beliefs may be formed. Experiences of different kinds may lead to changes in belief. However, such experiences are always interpreted through existing beliefs and tacit knowledge. As noted below, it is well acknowledge that individuals may cling to their existing beliefs in the face of evidence to the contrary: they pay more attention to evidence that supports their beliefs than to evidence which contradicts them. Some beliefs are acquired through induction and indoctrination: being told what to believe and how to behave, volunteering or being obliged to take on a role within a community or social institution. In contrast, beliefs may also be acquired through an education which encourages reflection on the logical coherence of propositions, the evaluation of historical records and the gathering and evaluation of empirical evidence. Education may also include reflection on the why and how of learning, encouraging one to 'learn how to learn'.

There is a set of experiences, known as 'transcendental' or 'mystical', where the individual claims to experience direct access to ultimate truths. Bucke (1905) refers to this form of knowing as "cosmic consciousness". It is a moot point as to whether these experiences have universal commonalities.9 Bucke believes they have and argues that such experiences lead to the founding of many (possibly all) of the world's 'religious' cults. There is a related set of experiential phenomena known as "shamanic", where adherents enter or create other "realities". Interesting though they are, these topics take us beyond the aims of the current paper. For more, see Scott $(1983,1996,2011)$.

Social identity theory (Tajfal, 1974) tells us that the individuals who are members of a group will tend to favour that group over other groups and share the beliefs of its members. We humans have a tendency to like structure in our lives and tend to follow leaders that provide it. We become accepting of the beliefs that the leaders promulgate. We humans - at least many of us - seem to have a need for explanations, answers to the 'big' questions about why we are here, where we came from, where we are headed, how the world works and how we should behave. We accept beliefs that lack empirical verification because they provide our lives with meaning.

\section{How Are Beliefs Changed?}

It is sometimes the case that, like good scientists, we humans change our beliefs when faced with logical contradictions or compelling empirical evidence. However, as many classic studies tell us we also on occasion behave irrationally. We are imperfect decision makers (Khaneman and Tversky, 1984). Our beliefs about 'reality' are distorted by 'cognitive dissonance': when there are differences between what we wish to believe and available evidence, we are often biased to select evidence that supports our beliefs rather evidence that contradicts them (Festinger, 1957). We seem to be especially reluctant to give up beliefs, especially core beliefs about who one is (Fein and Spencer, 1997; Spencer, Fein et al, 2001; Wolpert, 2006; Jung, 2011). In contrast, we may change our beliefs through a desire to conform to our peers or to submit to authority figures (Sherif and Sherif, 1953; Asch, 1954; Milgram, 1974).

\section{Conceptual Preliminaries}

It will be helpful at this stage to look at some key terms: Religion, Faith, Sect and Cult. 
What is a 'Religion'? As noted above, the term 'religion' is not well-defined: there are no once and for all defining criteria. At most we have a sense of 'family resemblance' between proposed exemplars (Wittgenstein, 1953). The etymology is obscure (L. re-ligare, rebind, reconnect). Shouler (2010, p.1)) offers this definition: "A 'religion' is an organized collection of beliefs, cultural systems, and world views that relate humanity to an order of existence." Note that this definition can also include the beliefs held by many agnostic and atheist scientists about the nature of the world and why they do what they do. A related and also not well-defined term is 'ideology'. It is usually used to refer to belief systems primarily concerned with politics and economics.

For present purpose it is useful to characterise 'religions' as belief systems that provide explanations of the meaning of life and explanations of how the world and other-worldly domains work, including all or some of the following: origins, constituents, laws, ways of knowing, ways of affecting, laws of conduct, ethical principles, judicial systems, jurisprudence, political systems, cultic and cultural traditions. The term 'faith' is frequently used as synonym for 'religion'. It emphasises the role of having confidence or trust in a person or entity. Faith is often contrasted with 'reason' as a way of arriving at 'truth', together with the argument that some particular truths can only be arrived at by faith. This view is sometimes referred to as 'fideism'. Ways of thinking and behaving that are not associated with a particular religion are described as 'secular' (L. saecularis, worldly).

The term 'cult' has several connotations. It can refer to religious practices (L. cultus, worship), to new religious movement or to secular movements devoted to a cause or personality. The normal hallmarks of a cult in the second sense are that there is an acknowledged source of authority and a defined set of beliefs and practices to which cult followers are expected to conform. By these criteria, many wellknown 'religions' began as cults.

The term 'sect' refers to subgroups that arise because of schisms within a 'religion'. (L. sequi, to follow; secare, to cut). Well established sects within a 'religion' are also referred to as 'denominations'.

\section{Main tenets of the three Abrahamic faiths}

This is not a work of deep, detailed scholarship covering the history and teachings of the three faiths. What I have done is consult some standard texts to obtain a broad brush stroke picture of each faith, its history, teachings and main variants. I have used these sources to obtain a skeletal conceptual template intended to capture the key similarities and differences between the faiths. I recommend Karen Armstrong (2001) book, The Battle for God, as a useful one volume quite detailed account of the three faiths and their complex and entangled histories ${ }^{10}$.

The conceptual template covers:

1. the existence and nature of God

2. God's purposes for man

3. teachings regarding human nature

4. teachings regarding right and wrong, good and evil

5. teachings regarding epistemology: how humans know what they can know

6. teachings regarding ontology: what is and how it came to be and what it will become.

7. teachings regarding heaven, hell and salvation.

8. teachings regarding divine intervention or other supernatural phenomena, including prophetic revelations and the miraculous. 
I do not discuss each of these topics in detail. I have used the template to organise my thinking and have then selected particular pertinent items for inclusion in the present discussion.

I have identified some beliefs that the major variants of the three faiths hold in common. These are: there is one 'holy" God (a belief known as 'monotheism', in contrast to 'polytheism', belief in many Gods); Abraham, who lived around 2000 BCE, is the patriarch to whom the one 'holy' God first revealed himself as the source of all power and all goodness and truth; there is the possibility of divine intervention (miracles and revelations); there will be a day of judgement when the world ends; there is a heaven and a hell; good and evil are absolutes; the divine purpose for mankind is to live by faith in God and to obey his commandments else be deemed a 'sinner'; all three have concepts of blasphemy, heresy and apostasy. The teachings of all three faiths are compiled in 'holy' books.

The percentages of followers of each faith in the world today out of a total population of seven billion are shown in figure 2. For completeness, data about the number of followers of other belief systems are also shown.

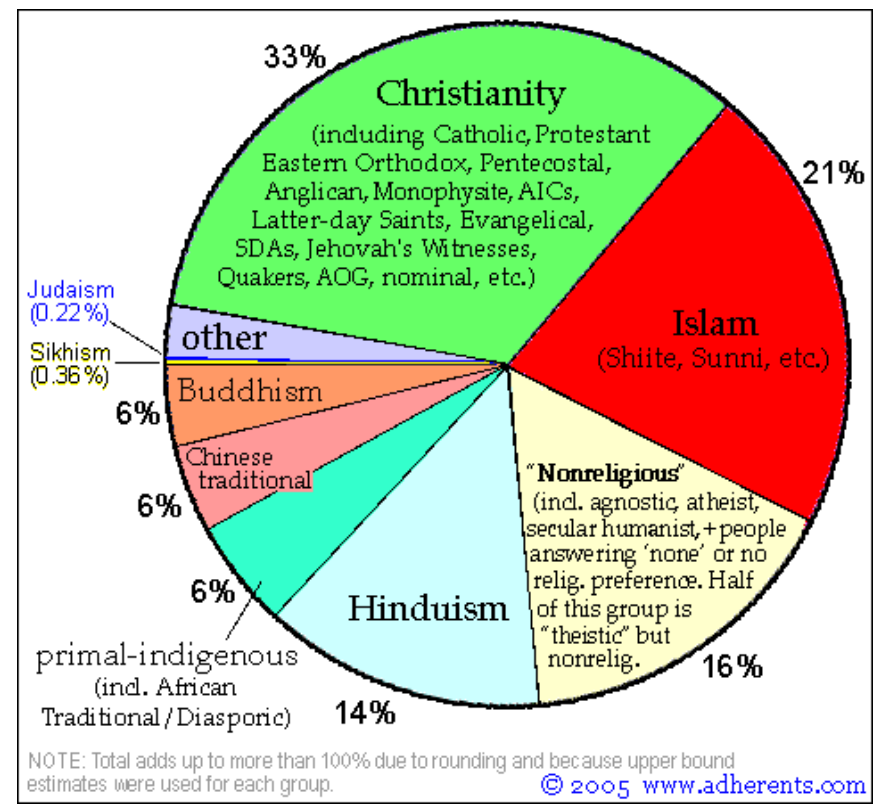

Figure 2 Typologies of Scenes Broadcast During Peaks The percentages of followers of 'religious' and 'non-religious' belief systems.

\section{Judaism}

Followers of Judaism are traditionally known as 'Jews'12. There are estimated to be fourteen million Jews in the world today, not all of whom practice Judaism in its various forms. This is because the main way to be classified as a Jew is to be born to a Jewish mother. In modern times, commentators regularly distinguish between 'religious Jews' and 'secular Jews'. Secular Jews, as well as not being practitioners of Judaism, can also be atheists yet still be considered to be Jewish. It is possible to become a Jew by conversion, in which case at least lip service adherence to the beliefs and customs of Judaism is expected. However, unlike Christianity and Islam, Judaism is not a proselytising faith, hence its relatively small numbers.

The foundational texts of Judaism (history, law, prophecies) are contained in the Tanakh, a collection of separate books. The first five books are known as the Torah. By tradition, the Torah is attributed to Moses, who was given the teachings by the one $\mathrm{God}^{13}$. These books tell how the Jews were called upon by God to be a chosen people: those to whom he revealed himself, to whom he gave his laws and with whom he made an a agreement (a covenant) that, in return for following his laws, they would flourish 
as a nation, that a Messiah (an 'anointed one') would come who would set up an eternal Jewish Kingdom. A total of 613 laws (mitzvot) are set out in the Torah. Additional teachings, interpretations and histories are collectively known as the Talmud. A summary of Jewish beliefs was proposed in the 12th century by Maimonides as thirteen 'articles of faith'. They are: God exists; God is one and unique; God is incorporeal; God is eternal; prayer is to God only; the prophets spoke truth; Moses was the greatest of the prophets; the Torah was given to Moses; there will be no other Torah; God knows the thoughts and deeds of men; God will reward the good and punish the wicked; the Messiah will come; the dead will be resurrected.

Judaism has undergone many schisms, spawning many sects, some of which no longer exist and are of historical interest only. This means there are many variants in how the core texts are interpreted and put into practice. In modern times the picture has become more complicated since the founding of a 'Jewish state', Israel, in 1948. A large majority of Jews live in the USA (estimated at 6.6 million). A slightly smaller number live in Israel (estimated at 6.3 million). Figure 3 shows a breakdown into different denominations of the Jews living in the USA. Details of the differences are not relevant here. The intent is to illustrate how complicated matters of belief can become as schisms occur. Similar but not identical differences between more liberal and more conservative sects are found amongst the 250,000 or so Jews who live in the UK as British citizens ${ }^{14}$.

The situation in Israel is particularly complicated, where denominational differences intersect with differences between ethnic origins (e.g., Ashkenazi from North East Europe, Sephardi from Portugal and Spain and Mizrahi from Arabia and Persia) and differences between political views, not least between pro and anti-Zionism. 'Zionism' refers to the avowed aim of maintaining a distinctly Jewish state. It is worth noting that there are both religious and secular Zionists and, vice versa, religious and secular anti-Zionists. The very concepts of what is a Jewish state and who is a Jew are unresolved. In recent years, the Israeli government extended citizenship to anyone who has a Jewish grandmother or grandfather. This is acknowledged to be a way for Israel to increase the number of Israeli citizens who are Jewish. Currently, $75 \%$ of Israeli citizens are Jewish ${ }^{15}$.

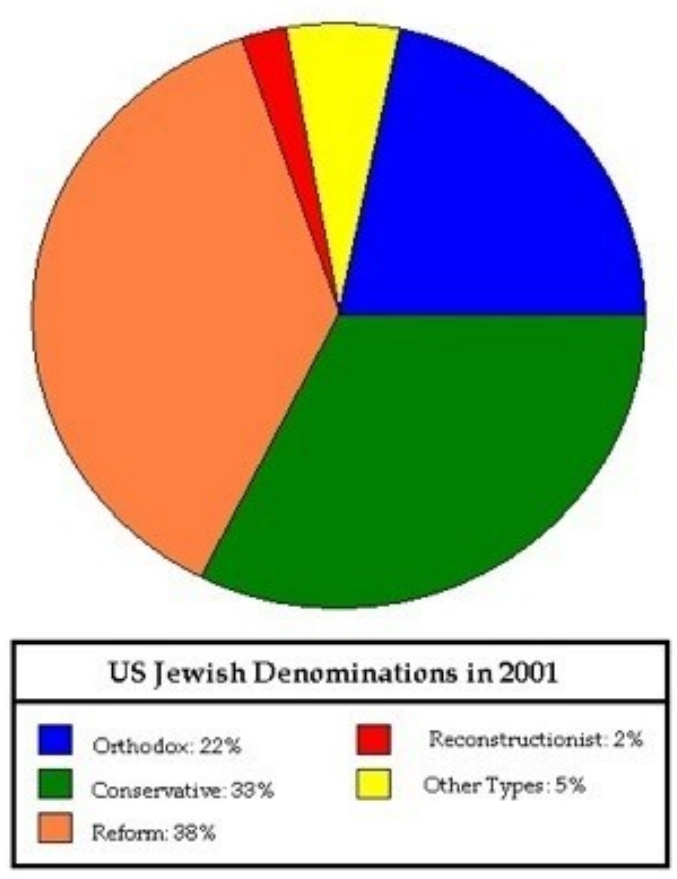

Figure 3 Jewish denominations in the USA 


\section{Christianity}

Strictly speaking, Christianity is a sect of Judaism, the key belief of Christians being that Jesus of Nazareth is the Messiah, long awaited by the Jews. Jesus can also be seen as the founder of a cult. It is acknowledged by contemporary Jewish and Roman accounts that Jesus was an historical figure who preached, performed miracles ('signs and wonders') and was put to death. Jesus Christ (the 'Christ' is taken from the Greek for Messiah) came not only for the Jews but also to be a 'light in the world' to spread the good news (O.E, godspel. the 'Gospel') of the coming of the 'Kingdom of God'. Jesus was crucified by the Romans at the behest of the Jewish priesthood. Christians believe that after his death Jesus was resurrected and that he appeared to his follower on several occasions before finally ascending into heaven. Following his departure, his followers were 'filled with the Holy Spirit' and began preaching about the Kingdom of God and the possibility of eternal life for those 'sinners' (people unacceptable to a holy God because they had broken his laws) who accepted Jesus as their Lord and saviour, teaching that Jesus, the only sinless man, had chosen to die for their sake as a sacrifice to God so their sins would be forgiven. Christianity is a proselytising 'religion'. When Jesus finally left the world, he gave his followers the 'grand commission' of taking the good news to all peoples of the world. Although the first Christians were Jews, the majority of his later followers came from non-Jewish


the Gospel'. There are approximately 2.2 billion Christians alive today

Canonical Christian teachings are to be found in the 'New Testament', compiled in the 4th century CE. The New Testament includes four accounts of the life of Jesus (known collectively as the 'Gospels'), an account of some of the activities of Jesus' followers after his death ('The Acts of the Apostles), letters written by evangelists and 'The Book of Revelation', a prophetic work consisting mainly of allegorical visions attributed to Saint John, one of Jesus' original disciples. Christian's also include the Jewish Tanakh as a 'holy book', referring to it as the 'Old Testament'. However, the texts are interpreted from a Christian perspective as providing evidence about Jesus' coming into the world and the nature of his mission, including prophecies about his death and resurrection.

Jesus, at least as interpreted by Christians, can be viewed as a reformer of Judaism in that (i) he emphasises that through belief in him one can have a personal relationship with God; thus there is no longer the need for a separate priesthood to act as intermediaries between God and the individual (ii) he does away with need for dietary laws. The early evangelists, after some controversy, agreed that one can be a Christian without having to first become a Jew (being circumcised, abiding by the mitzvot). To become a Christian, it is enough to accept Jesus as one's Lord. It is customary to be baptised (immersion or partial immersion in water) to symbolise death of the old sinful self and rebirth as a 'new creation', and to receive 'baptism in the Holy Spirit', a personal experience of being 'born again of the Spirit', of being 'filled with the Holy Spirit' and of becoming part of the Kingdom of God. Christian denominations vary in the emphasis they put on these practices and experiences. Saint Paul, whose teachings about being a Christian are contained in letters collected in the New Testament, describes several 'gifts' and 'fruits' of the Holy Spirit. The gifts are: Wisdom, Knowledge, Faith, Healings, Miracles, Prophecy, Discernment of spirits, Tongues, Interpretation of tongues. The fruits are: Love, Joy, Peace, Patience, Kindness, Goodness, Gentleness, Faithfulness, Self-Control.

Jesus is also recognised by many as a great teacher of wisdom and ethics, who taught his followers not only to 'love their neighbours' (a command in Judaism) but also to 'love their enemies'.

In its 2,00o year history, Christianity has been subject to many schisms and many sects have been formed. There are reportedly 41,000 Christian denominations in the world today. Some major divisions are shown in figure 4 . 
For more details, see http://en.wikipedia.org/wiki/List_of_Christian_denominations and http://www.pewforum.org/2011/12/19/global-christianity-exec/.

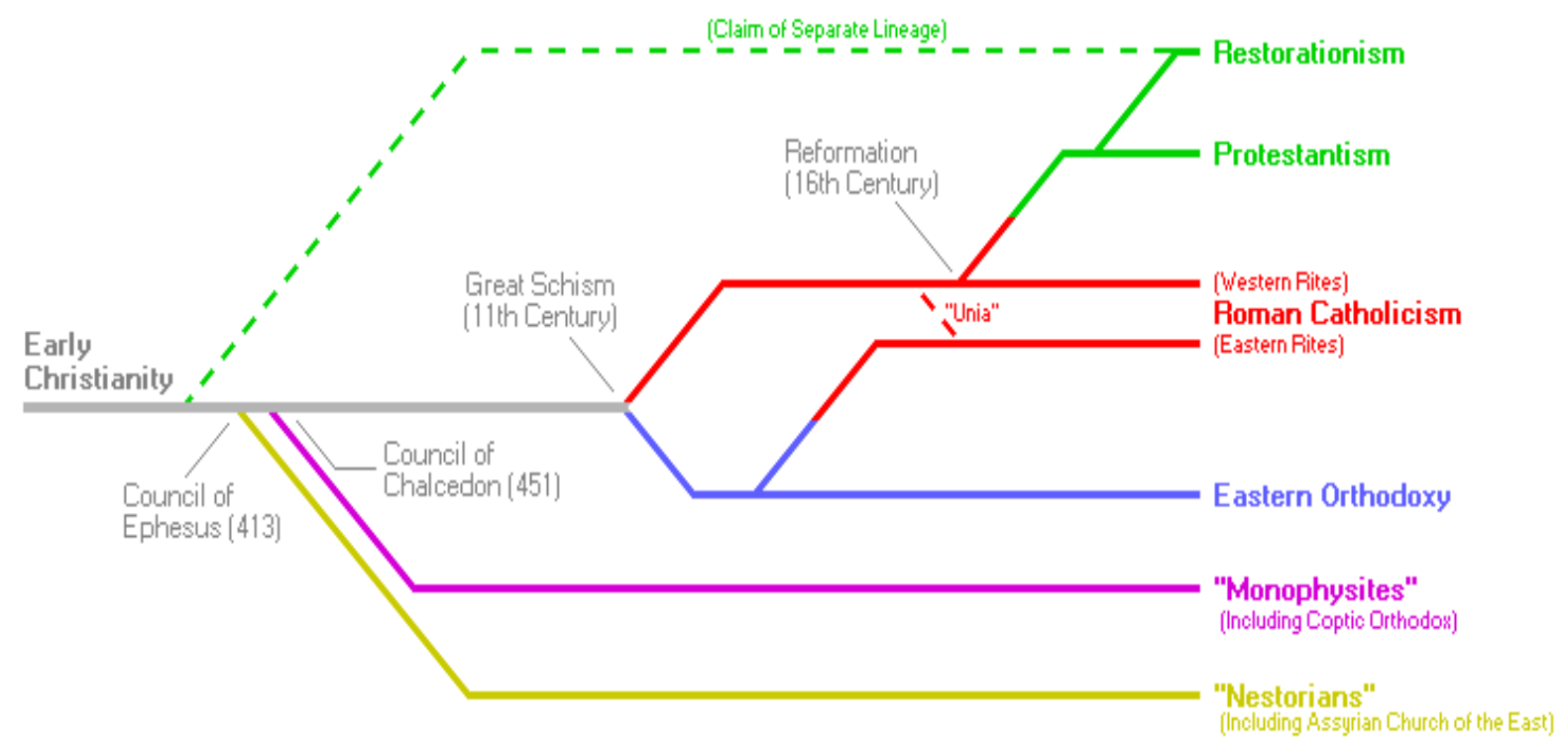

Figure 4 Major divisions in Christianity ${ }^{16}$

Amidst the variety, there is also some uniformity, as a majority of Christians accept the teachings agreed by early Christian leaders in $325 \mathrm{CE}$, at a meeting in Nicea, The teachings are known as the 'Nicene Creed':

"I believe in one God, the Father Almighty, Maker of heaven and earth, and of all things visible and invisible.

"And in one Lord Jesus Christ, the only-begotten Son of God, begotten of the Father before all worlds; God of God, Light of Light, very God of very God; begotten, not made, being of one substance with the Father, by whom all things were made.

"Who, for us men and for our salvation, came down from heaven, and was incarnate by the Holy Spirit of the virgin Mary, and was made man; and was crucified also for us under Pontius Pilate; He suffered and was buried; and the third day He rose again, according to the Scriptures; and ascended into heaven, and sits on the right hand of the Father; and He shall come again, with glory, to judge the quick and the dead; whose kingdom shall have no end.

"And I believe in the Holy Ghost, the Lord and Giver of Life; who proceeds from the Father and the Son; who with the Father and the Son together is worshipped and glorified; who spoke by the prophets.

"And I believe in one holy catholic and apostolic Church. I acknowledge one baptism for the remission of sins; and I look for the resurrection of the dead, and the life of the world to come. Amen."

\section{Islam (1.5 billion)}

Islam (Arabic, submission) is a cult, founded by Mohammed (born c. $570 \mathrm{CE}$ ). Members of the cult are known as 'Muslims'. Muslims do not consider Mohammed to be the founder of a cult. They consider him to have been the restorer of an original monotheistic faith that began with Adam and was promulgated by Noah, Abraham, Moses, Jesus, and other prophets. Islam is the final revelation. It was needed because neither Jews nor Christians (apart from a few righteous individuals) could live up to 
God's callings. Mohammed's own revelation came when he was 40 years old. According to his own account, he was visited by the Angel Gabriel who, in a series of encounters over a number of years, dictated to Mohammed numerous sayings covering a wide range of topics, including: an Islamic version of the history of God's dealings with Jews and Christian, laws and admonitions on how to manage a Muslim community, how to deal with 'unbelievers', and advice on how to spread Islam and deal with its enemies. Mohammed himself was illiterate. His personal knowledge and understanding of Judaism and Christianity would have come from his travels as a merchant. The sayings were written down by his followers and compiled as a collection of 'verses' into a 'holy' book known as the Koran (Arabic, the recitation). The language of the verses is poetic, akin to the style of Arab poets and story tellers of the day. It is said by Arabic speakers to be the highest expression of that art. The Koran and the Hadith (a collection of stories about Mohammed's life) are the key texts on which the beliefs and practices of Muslims are based. Sharia, Muslim moral codes and laws, are derived from these texts. Mohammed is considered by Muslims to be a perfect man, so what he said and did are taken as exemplars to be followed.

Mohammed was not only a religious leader he was also a political and military leader. Historical accounts tell us Islam was spread mainly by warfare and conquest. Mohammed himself led armies that conquered large parts of the Arabian Peninsula. His followers, in a series of waves between the 7 th and 19th centuries, went on to conquer North Africa, Spain, the Balkans and large parts of central and south East Asia. Islam has also spread more peacefully by immigration in China and parts of Europe and the Americas.17

In many ways, Islam is akin to Judaism: both Moses and Mohammed were religious, political and military leaders who received revelation from the one God. Both teach that submission to God's will and obedience to his laws are the way to enter 'paradise' after death. However, For Jews the Torah is the source of God's teachings; Islam is thus heretical. Islam denies the core of Christian teaching about the impossibility of living up to laws and, because all "fall short of the glory of God", there is a need for Jesus as the saviour of mankind and that "salvation is by faith alone". Both the resurrection and the divine nature of Jesus are denied. Thus, for Christians, too, Islam is heretical.

The key belief of Muslims is that, "There is no God except Allah and Muhammad is His messenger". To accept this is to become a Muslim. In full, there are "Seven Articles of Faith": belief in God, his angels, his revealed books, his messengers, the Last Day, that fate (good and bad) is predestined by Allah and that there is resurrection after death.

Muslims are called upon to practice "The Five Pillars of Islam":

Shahadah: sincerely reciting the Muslim profession of faith

Salat: performing ritual prayers in the proper way five times each day

Zakat: paying an alms (or charity) tax to benefit the poor and the needy

Sawm: fasting during the month of Ramadan

Hajj: pilgrimage to Mecca a least once in one's lifetime.

In its version of Judaism and Christianity, Islam recognises them as other "Children of the Book", to whom God has given revelation in holy texts. "Surely, those who believe, those who are Muslims, Jewish, the Christians, and the Sabians18; anyone who (1) believes in God, and (2) believes in the Last Day, and (3) leads a righteous life, will receive their recompense from their Lord. They have nothing to fear, nor will they grieve." Koran, 2.62. In Sharia Law, Jews and Christians are permitted to live in an Islamic state but are subject to restrictions on their activities and are obliged 
to pay a tax, the 'jizyah'. Those subject to these restrictions are known as 'dhimmis'19. The restrictions have been (and are) more repressive under certain regimes than others. Islam is the only one of the Abrahamic faiths (indeed, of the world's major faiths) that does not apply the 'Golden Rule', "Do unto others as you would have them do unto you", universally.20

In Sharia law, women have a special status, in many ways subordinate to that of men. The restrictions that are applied or have been applied vary under different regimes21. In Sharia law, it is also the case that apostasy (leaving Islam) is punishable by death. In modern Islamic states punishments for apostasy differ but sanctions of some kind are common. In most Islamic states, if one has a Muslim parent, one is a Muslim from birth. It can be extremely difficult to change that status, should one, for example, convert to a different faith.

Shortly after Mohammed's death, there was a major schism over who should succeed him. This lead to the existence of two major sects: The Shias and the Sunnis. This schism continues to be the source of political and military conflict.22 Over the centuries, there have been many other schisms, as illustrated in figure 5 . One major way in which the sects differ is the extent to which they interpret the teachings of Islam in traditional or more liberal ways. Traditionalists wish to live under strict versions of Sharia law. They also typically support the ultimate goal of establishing a 'global Caliphate', a one world Islamic state. More liberal sects emphasise the 'spiritual' rather than political aspects of Islam and embrace the Western values of democracy and multi-culturalism.23



Figure 5 Major divisions in Islam

\section{Sociocybernetic analysis}

The brain/body biological systems that embody belief systems are 'organisationally closed'. The systems in question remain viable as long as the system continues to reproduce itself from moment to moment. Whatever else it may produce as behaviours or other products of its functioning, the system 
must reproduce its own embodiment as a coherent system. Maturana (Maturana and Varela, 1980) call such systems 'autopoietic' (self-constructing). ${ }^{24}$ The form of the organisation may be modified as it adapts to external influences as long as the organisation continues to reproduce itself. Autopoietic systems adapt and learn. Humans, as they develop and interact with other humans, learn how to use symbolic means to communicate with others and with themselves. Indeed, the 'self' itself becomes capable of self-observation and self-description. Ultimately, all these changes are just more and more complex forms of adaptation. 'Knowledge' is acquired by processes of construction. Events tha perturb the system are given meaning. Belief systems are constructed. ${ }^{25}$ However, the human ability to construct knowledge is frequently trivialised and abused by processes of indoctrination. The individual is told what to believe, is told what is 'the truth'. Such indoctrination denies the very nature of humans as autopoietic constructers of knowledge. It becomes 'brain washing'. Minds become enchained.

Understanding that all knowing is the result of the constructive adaptive activity of an organisationally closed system shows us not only that efforts to put, implant or transfer knowledge into someone make a travesty of the human ability to learn, it also helps us recognise that there are limits on what may be known. An autopoietic adaptive system cannot hope to 'know' the whole of which it is a part. As von Foester $(1992,2003)$ puts it, "There are undecidables." ${ }^{26}$ There are questions for which the 'true' answer can never be known. The best one can do is, on the evidence available and as a matter of personal predilection, construct a narrative that one finds more or less satisfying. Is there a God? How did the world begin? How will it end? Are there absolutes of 'good' and 'evil'? These are examples of undecidable questions. Von Foerster (1992) goes on to say that the fact that we can choose how to answer these questions for ourselves is what gives us our freedom as human beings. There are then ethical implications for these epistemological limits. If we are free to choose the answers to undecidable questions, we should take responsibility for having made those choices.

We are now in a position to identify why some belief systems are pathological. Not only do they limit what and how one may think and learn, they limit our behaviour, including our freedoms to interact with one another. Ashby's Law of Requisite Variety states that, "Only variety can control variety" (Ashby, 1956). If we are to deal at all effectively with the many problems facing mankind we should be encouraging open-ness and cooperative interaction, not imposing unnecessary limits. ${ }^{27}$ Pask (1991) refers to 'the right of actors to interact' as a fundamental human freedom. Cybernetically, 'evil' is whatever limits that right unnecessarily. Obviously, some safeguards are needed to protect the young, the innocent and the vulnerable. What limits are 'unnecessary' is a matter for democratic debate.

There are a number of ways in which the beliefs to be found in the texts and traditions of the Abrahamic faiths may be considered to be pathological: dietary laws, restrictions on females, discrimination against the other faiths and unbelievers; irreconcilable conflicts between the faiths, including denial of each other's legitimacy, competing claims on 'The Holy Land' and 'holy' places, the establishment of priestly hierarchies, separate from ordinary believers, that control access to God and 'the truth'. ${ }^{28}$

\section{Concluding comments}

To address global problems, we need to critically appraise all the world's belief systems for the ways in which they have 'minds in chains'. We need to provide education that leads to better understandings of the human condition, including understandings of how humans learn and what may be known. In Scott (2014), I sketch out a proposed curriculum for an "education for cybernetic enlightenment". Foundational to this curriculum are the understandings that we share one gene pool and that we become human by being part of a human community. In our explorations of the human condition and the undecidable questions that pertain to it, we may of course choose to accept the teachings of particular faiths. It is then important that we accept responsibility for our choices as those that we 
have made freely. It is also important that we accept only those teachings that do not limit the right of actors to interact. Thankfully, such teachings do exist. In the Jewish Torah, one is commanded to love God and to love one's neighbour as oneself. Jesus of Nazareth made these commandments central in his teachings and, as instanced in the parable of the Good Samaritan, gave them universal application. ${ }^{29}$ These commandments do not require uniformity or conformity. On the contrary, they call for acceptance amidst variety: "He who is not against us is for us" (Mark, 9, 40). In ancient China, the ideal of aspiring to universal fellowship was set out by Confucius and his followers. In ancient India, the Buddha advocated one to have compassion for all. Now in the $21^{\text {st }}$ century, thanks to the ubiquity of "social media", there is the possibility of raising awareness and understanding of the human condition like never before. ${ }^{30}$

As Pask (1969) points out, whilst there are limits on what may be known and what may be done, the adventure of being human is open-ended. We can aspire to explore new forms of knowing and experiencing. We can aspire to create joyful and fulfilling ways of living. The final story has not yet been told. As we come to understand how we co-construct ourselves and our worlds, we can foster and nurture those understandings. In moments of optimism, I am encouraged by the possibility that these new forms of shared awareness can cast aside all the chains, not just the mental ones, whereby humans in their ignorance abuse one another. Throughout history, all abusive power structures, all hierarchies of control, have been undermined. Even if they survive for millennia, they are temporary structures. The fundamental human condition is heterarchical ${ }^{11}$. Through our sometimes conflicting and sometimes co-operating interactions, power hierarchies come and, eventually, collapse. Second order cybernetics makes clear that we are observers who co-construct shared "realities". ${ }^{32}$ Humberto Maturana outlines what a truly "human society" is like when we choose to co-create one: it is " ... A product of human art, that is, an artificial society that admits change and accepts every human being as not dispensible. Such a society is necessarily a non-hierarchical society for which all relations of order are constitutively transitory and circumstantial to the creation of relations that continuously negate the institutionalization of human abuse. Such a society is in its essence an anarchistic society, and society made for and by observers that would not surrender their condition of observers as their only claim to social freedom and mutual respect" (Maturana and Varela, 1980, Introduction, Point 15).

This is our condition as individual observers now, should we choose to see it as such. Let us choose to work to make this condition universally accepted. To do so, it behoves us to "Be wise as serpents and innocent as doves." (Matthew 10, 16).

\section{References}

Armstrong, K. (2000). The Battle for God. Ballantine, New York.

Asch, S. E. (1955). “Opinions and Social Pressure”. Scientific American, 193 (5): 31-35.

Ashby W R. (1956). An Introduction to Cybernetics. New York: Wiley.

Beltz, W. (1983). God and the Gods. Penguin Books, Harmondsworth, Middx.

Bloom, H. (2013). The Mohammed Code. www.gopublished.com.

Broadbent, E.H. (1931). The Pilgrim Church. Pickering and Inglis Ltd, Basingstokw, Hants.

Bucke, R.M. (1905). Cosmic Consciousness. Innes and Sons, Philadelphia, PA.

Dawood, N.J. (1956). The Koran. Penguin, Harmondsworth, Middz.

Dimont, M.I. (1994). Jews, God and History. Revised and updated edition. Mentor, New York.

Dirks, J.F. (2004). The Abrahamic Faiths. Amana Publications, Beltsville, Maryland. 
Fein, S. and Spencer, S.J. (1997). "Prejudice as self-image maintenance: affirming the self through derogating others", Journal of Personality and Social Psychology, 73, 1, 31-44.

Festinger, L. (1957). A Theory of Cognitive Dissonance. Stanford, CA: Stanford University Press.

Gillani, N. (2003). "Islamic Humanism”. The Ismaili USA, March 23 2003.

Glanville, R. (2002). "Second order cybernetics". Invited chapter for Encyclopedia of Life Support Systems, UNESCO. http://www.eolss.net/. Reprinted as chapter 1.11 of Glanville R (2012) Cybernetic Circles, The Black Boox, Volume 1.echoraum-WISDOM, Vienna, 175-208.

Glanville R (2012). “Objects”. Chapter 2.o1 of Cybernetic Circles, The Black Boox, Volume 1.echoraumWISDOM, Vienna, 231-322.

Glanville, R. (in press). "Cybernetics: thinking through the technology”. In Arnold, D. (ed.) Traditions of Systems Theory: Major Figures and Contemporary Developments. Routledge, New York.

Huntington, S.P. (1996). The Clash of Civilizations and the Remaking of World Order. Simon and Schuster, New York.

James, W. (1902). The Varieties of Religious Experience. Longmans, Green and Co., Bombay.

Jung, R, (2011). Experience and Action. echoraum, Vienna.

Kahneman, D and Tversky, A. (1984). "Choices, values and frames". American Psychologist, 39 (4):341350.

Layton, B. (1987). The Gnostic Scriptures. SCM Press, London.

Lloyd-Jones, D. M. (1984). Joy Unspeakable: The Baptism and Gifts of the Holy Spirit. Kingsway Publications, Eastbourne, Sussex.

Maturana, H. R. \& Varela, F. J. (1980). Autopoiesis and Cognition. Reidel: Dordrecht.

Milgram, S. (1974). Obedience to Authority: An Experimental View, Tavistock Publications, London.

Nasr, V. (2006). The Shia Revival, Norton, New York.

Pask G. (1969). The meaning of cybernetics in the behavioural sciences. In Progress of Cybernetics, Vol. 1, J Rose, ed. New York: Gordon and Breach, 15-44.

Pask, G. (1991), "The right of actors to interact: a fundamental human freedom”, in Glanville, R. and de Zeeuw, G. (Eds), Mutual Uses of Cybernetics and Science (Vol 2), Systemica, Vol. 8, Thesis Publishers, Amsterdam.

Pask G. (1996). "Heinz von Foerster's self-organisation, the progenitor of conversation and interaction theories". Systems Research, 13, 3, pp. 349-362.

Rescher, N. (1973). Conceptual Idealism, Basil Blackwell, Oxford.

Rescher, N. (1977). Methodological Pragmatism, Basil Blackwell, Oxford.

Rodinson, M. (1974). Mohammed. Penguin, Harmondsworth, Middx.

Rogerson, J. (ed.) (2001). The Oxford Illustrated History of the Bible, OUP, Oxford.

Sherif, M., \& Sherif, C. W. (1953). Groups in Harmony and Tension. New York: Harper \& Row.

Scott, B. (1983). "Morality and the cybernetics of moral development", Int. Cyb. Newsletter, 26, 520-530. Reprinted as chapter 5 in: Scott, B. (2011). Explorations in Second Order Cybernetics: Reflections on Cybernetics, Psychology and Education. echoraum, Vienna. 
Scott, B. (1996). "Second-order cybernetics as cognitive methodology”, Systems Research 13, 3, 393-406. Reprinted as chapter 14 in: Scott, B. (2011). Explorations in Second Order Cybernetics: Reflections on Cybernetics, Psychology and Education. echoraum, Vienna.

Scott, B. (2002). "Being holistic about global issues: needs and meanings", J. of Sociocybernetics, 3, 1, pp. 21-26. Reprinted as chapter 21 in: Scott, B. (2011). Explorations in Second Order Cybernetics: Reflections on Cybernetics, Psychology and Education. echoraum, Vienna.

Scott, B. (2004). "Second order cybernetics: an historical introduction", Kybernetes, 33, 9/10, 13651378. Reprinted as chapter 24 in: Scott, B. (2011). Explorations in Second Order Cybernetics: Reflections on Cybernetics, Psychology and Education. echoraum, Vienna, 383-398.

Scott, B. (2006). "Reflexivity revisited: the sociocybernetics of belief, meaning, truth and power", Kybernetes, 35, 3/4, pp. 308-316. Reprinted as chapter 26 in: Scott, B. (2011). Explorations in Second Order Cybernetics: Reflections on Cybernetics, Psychology and Education. echoraum, Vienna.

Scott, B. (2009). "The role of sociocybernetics in understanding world futures". Kybernetes, 38, 6, pp. 867-882. Reprinted as chapter 32 in: Scott, B. (2011). Explorations in Second Order Cybernetics: Reflections on Cybernetics, Psychology and Education. echoraum, Vienna.

Scott, B. (2011). "Reflections on unity, forms of knowledge and the form of knowing." chapter 4 in: Scott, B. (2011). Explorations in Second Order Cybernetics: Reflections on Cybernetics, Psychology and Education. echoraum, Vienna.

Scott, B. (2012). "Using the logic of life to reduce the complexity of life", Cybernetics and Human Knowing, 19, 3, 93-104.

Scott, B. (2014). "Education for cybernetic enlightenment". Cybernetics and Human Knowing, 21, 1-2, 199-205.

Scott, B, and Bansal, A. (2014). "'Learning about learning: a cybernetic model of skill acquisition", Kybernetes, 43, 9/10, $1399-1411$.

Shouler, K. (2010). The Everything World's Religions Book: Explore the Beliefs, Traditions and Cultures of Ancient and Modern Religions. Adams Media, Cincinnati, OH.

Spencer, S.J., Fein, S. and Lomore, C.D. (2001). "Maintaining one’s self-image vis-'a-vis others: the role of self-affirmation in the social evaluation of the self". Motivation and Emotion, 25, 1.

Suppe, F. (1977). "The search for philosophic understanding of scientific theories" and "Afterword 1977", in Suppe, F. (Ed.), The Structure of Scientific Theories (2nd ed.),

University of Illinois Press, Urbana, IL, pp. 3-230 and 617-729.

Tajfel, H. (1974). "Social identity and intergroup behaviour”. Social Science Information, 13, 65-93.

Ungar, M.F. and Larson, G.N. (1984). The Hodder Bible Handbook. Hodder and Stoughton, London.

Von Foerster, H. (1992). "Ethics and second-order cybernetics", Cybernetics and Human Knowing, 1, 1, 40-46. Available at http://www.flec.kvl.dk/sbr/Cyber/cybernetics/voli/vi-1hvf.htm .

Von Foerster, H. (2003) Understanding Understanding: Essays on Cybernetics and Cognition. Springer, New York.

Wittgenstein, L. L. (1953). Philosophical Investigations. Basil Blackwell, Oxford.

Wolpert, L. (2006), Six Impossible Things Before Breakfast: The Evolutionary Origins of Belief. Faber \& Faber, London. 
${ }^{1}$ Thanks to my friends Dr James Petch and Dr Alexander Riegler who gave the paper close readings and made many suggestions for improvements.

${ }^{2} \mathrm{http}$ ://sociocybernetics.wordpress.com/conferences/.

3 Here, sociocybernetics is broadly understood as the application within the social sciences of concepts taken from cybernetics and other disciplines concerned with complex systems.

4 The figure is adapted from Rescher (1980), who uses it in his discussion of the philosophy of science. I use it in a more general sense for any system of beliefs.

5 See Suppe (1977) for an authoritative analysis of this concept.

${ }^{6}$ As discussed further below, the concept of what is a 'religion' is not well-defined.

${ }^{7}$ As a creative activity, science generates novel problems, methods and theories. This is also a form of 'divergence'. However, the continued application of the scientific method ensures that such divergences are only temporary.

${ }^{8}$ It should be noted that disputation (about interpretation of rules, for example) may serve as an ongoing refinement process in authoritative belief systems, albeit carried out within a relatively rigid framework.

${ }^{9}$ For a different view, see William James' classic text, The Varieties of Religious Experience (James, 1902).

${ }^{10}$ It would be remiss not to a least mention the conflicting beliefs that exist about who did what to whom, how, when, where and why. Discussion of these issues requires an historical geopolitical analysis well beyond the scope of this paper. Huntington's (1996) book, The Clash of Civilizations and the Remaking of World Order, is a controversial attempt at such an analysis.

${ }^{11}$ The term 'holy', as used in English, has a composite of meanings: whole, set apart, sacred, righteous, pure, perfect, revered (proto-Germanic, hailaz, healthy, whole).

${ }^{12}$ I recommend Max Dimont's (1994) book, Jews, God and History, as very readable history of the Jews written by a Jew.

${ }^{13}$ A readable account of what is known about the origin of the written texts can be found in The Oxford Illustrated History of the Bible, Rogerson, J. (ed.) (2001).

${ }^{14}$ For data on Jewish populations per country, see http://en.wikipedia.org/wiki/Jewish_population_by_country, accessed 29/10/13.

${ }^{15}$ For more on the demographics of Israel, see http://en.wikipedia.org/wiki/Demographics_of_Israel , accessed $16 / 12 / 14$.

16 There are a multitude of texts that tell the story of how Christianity was adopted as the state religion by the Roman Empire and how the Church of Rome became dominant over other churches. There are far fewer 'restorationist' accounts that tell the story of those Christians who remained outside Rome's fold. I recommend Edmund Broadbent's (1931) book, The Pilgrim Church.

${ }^{17}$ I have consulted many texts about Islam, some more sympathetic than others, and different versions of the Koran. For a reasonably impartial account of Mohammed's life, I recommend Rodinson (1974). For a readable translation of the Koran into English, I recommend Dawood (1956). Of particular interest to the readers of this journal is a recent history of Islam that uses meme theory and the theory of complex adaptive systems in its account of how and why Islam has been so successful in its rise and in preserving its central characteristics, see Bloom (2013).

18 The Sabians were a monotheistic sect found in Arabia at the time of Mohammad but no longer exist.

${ }^{19}$ For more on this topic, see https://sites.google.com/site/islamicscripturesunveiled/Home/dhimmi (accessed 26/11/13).

${ }^{20}$ Versions of the Golden Rule are to be found in Islamic texts but, in the context of other teachings, it is clear that they apply only within the Islamic community. See http://en.wikipedia.org/wiki/Golden Rule (accessed 28/11/13).

${ }^{21}$ For more, see http://freethoughtnation.com/contributing-writers/63-acharya-s/574-what-does-the-koransay-about-women.html (accessed 26/11/13).

${ }^{22}$ A recent global survey of Sunni and Shia conflicts, with historical background, can be found in Vali Nasr's (2006) The Shia Revival. Nasr reveals much about how Sunni Saudi Arabia and Shia Iran have competed for influence in recent decades.

23 The Shia Ismaili sect is an example. See http://www.akdn.org/about agakhan.asp (accessed 26/11/13) and Gilliani (2003).

24 "Autopoiesis is that organization which computes its own organization"; "Autopoietic systems are thermodynamically open but organizationally closed" (Von Foerster, 2003, p. 281).

${ }^{25}$ For more on the dynamics of human learning, see Scott and Abhinav (2014). 


\footnotetext{
${ }^{26}$ There is a large literature concerning the existence of epistemological and pragmatic limits on what may be known and what may be done. As further examples, Bertrand Russell () states that to know the 'why' of the world would be to know the mind of God and that to know the 'how' of the world would be to know God as prime mover. Gordon Pask (1996) tersely states that life is ineffable and ineluctable.

${ }^{27}$ I have discussed this topic in more detail elsewhere (Scott, 2009; Scott, 2012).

${ }^{28}$ As an example, Pope Francis has said that without the Church, one is not a Christian

(http://www.christianpost.com/news/pope-francis-without-the-church-you-are-not-a-christian-119827/, accessed 09/12/14). He is referring to his own Church, the Church of Rome., which functions with a priestly hierarchy that is based on territorial jurisdiction (parishes, dioceses and archdioceses). In contrast, St. Peter refers to all believers in Christ as "a royal priesthood" (1 Peter, 2, 9). In similar spirit, St. John refers to believers as "kings and priests" (Revelation 1.6).

${ }^{29}$ As noted earlier, Islamic versions the Golden Rule only apply to Muslims.

$3^{30}$ The same media can of course be used to promote pathological beliefs.

${ }^{31}$ 'Heterarchy' refers to a form of organisation that has no fixed overall ruler. For more on the term and its relation to power hierarchies, see Scott (2006)

${ }^{32}$ I particularly recommend the writings of Ranulph Glanville on this topic (Glanville, 2002, 2012, in press). In his own original contribution to second order cybernetics, the theory of "Objects", Glanville takes as a starting point the concept that observation and self-observation are complementary non-intersecting processes that necessarily bring forth temporal and spatial worlds of experience.
} 